\title{
SULFONAMIDE-FAST PNEUMOCOCCI. A CLINICAL REPORT OF TWO CASES OF PNEUMONIA TOGETHER WITH EXPERIMENTAL STUDIES ON THE EF- FECTIVENESS OF PENICILLIN AND TYROTHRICIN AGAINST SULFONAMIDE-RESISTANT STRAINS
}

\author{
By WILLIAM S. TILLETT, MARGARET J. CAMBIER, AND \\ WILLIAM H. HARRIS, JR. \\ (From the Department of Medicine, New York University College of Medicine and the Third \\ Medical Division of Bellevue Hospital, New York)
}

(Received for publication October 22, 1942)

Demonstration of the fact that strains of pneumococci may become resistant to the antibacterial action of the sulfonamide drugs has emphasized one of the potential difficulties that may arise in the chemotherapy of pneumonia. Not only has the acquisition of drug-fastness been induced by laboratory procedures ( 1 to 3 ) but individual strains of pneumococci obtained from patients have exhibited the capacity to change within the body from susceptible to resistant states during the course of treatment (4 to 7 ).

The findings recorded in this report were derived from observations on two patients who had pneumococcus pneumonia with bacteremia and who failed to respond to sulfadiazine but improved rapidly following serum therapy. Clinical and laboratory data are presented which indicate that the infections were caused by drug-resistant pneumococci. In addition, the patients' strains have been used for experimental studies with particular reference to problems relating to treatment. For this purpose, infected mice have been treated with penicillin and with tyrothricin, as well as with sulfadiazine, in order to compare the curative action of the three agents.

\section{CLINICAL AND LABORATORY DATA OF THE PATIENTS}

The pertinent findings in the course of the diseases in the two patients are given in Figure 1 for patient $M$. $R$., who had Type I pneumococcus pneumonia, and in Figure 2 for patient W. L., who had Type VIII pneumococcus pneumonia (Figure 1).

Patient M. R. was a white female, aged sixty-two years. She was admitted on the fourth day of the disease and was found to be seriously ill with pneumonic consolidation of the right lower and middle lobes. The leukocyte count was 9,900. There was no sputum. Blood culture was positive for pneumococcus Type I. Sulfadiazine was administered on the first hospital day, both intravenously and by mouth. From Figure 1, it may be noted that her temperature dropped to $100^{\circ} \mathrm{F}$., on the third hospital day. However, clinical evidence of improvement did not parallel the temporary fall in temperature. On the fourth hospital day, the fever had risen again above $102^{\circ} \mathrm{F}$.

Pneumococcus Type I was obtained from a throat culture taken on the seventh hospital day. A second blood culture, taken on the eighth hospital day, was also positive for pneumococcus Type I.

The patient remained acutely ill and bacteremia persisted in spite of the maintenance of blood levels of sulfadiazine ranging from 9.1 to $13.4 \mathrm{mgm}$. per cent. Consequently Type I antipneumococcus rabbit serum was administered as indicated in Figure 1. The drop in the temperature was attended with marked clinical improvement. Subsequent blood cultures were sterile. The patient recovered uneventfully.

From the course of the disease in this patient, both with respect to the persistence of signs and symptoms of acute illness as well as the bacteremia, it is evident that sulfadiazine was not effective even though the disease was limited to a primary uncomplicated pneumonia. Although the first two blood cultures were taken a week apart, the absence of any clinical improvement during the first eight days is strongly suggestive that the bacteremia may have been continuously present. Furthermore, the simultaneous presence in the blood stream of both pneumococci and appreciable levels of sulfadiazine indicate the absence of antibacterial action of the drug on the infecting organisms. When these findings are correlated with the failure of sulfadiazine, as shown later on, to cure mice infected with the strain of pneumococci derived from this patient, the conclusion seems clear that the drug-fast characteristics of the infecting organisms accounted, in all probability, for the patient's lack of response to chemotherapy.

The strain of pneumococcus Type I from patient M. $R$. which was subsequently used for laboratory tests was isolated from a throat culture taken on the seventh hospital day. Conclusive evidence, therefore, of the nature of the strain before the beginning of treatment was not determined. However, the persistence of active illness, in spite of adequate administration of sulfadiazine, suggests that the infecting organism was either resistant from the beginning or had quickly acquired the property.

Patient W. L. (Figure 2) was a colored male, aged 50 


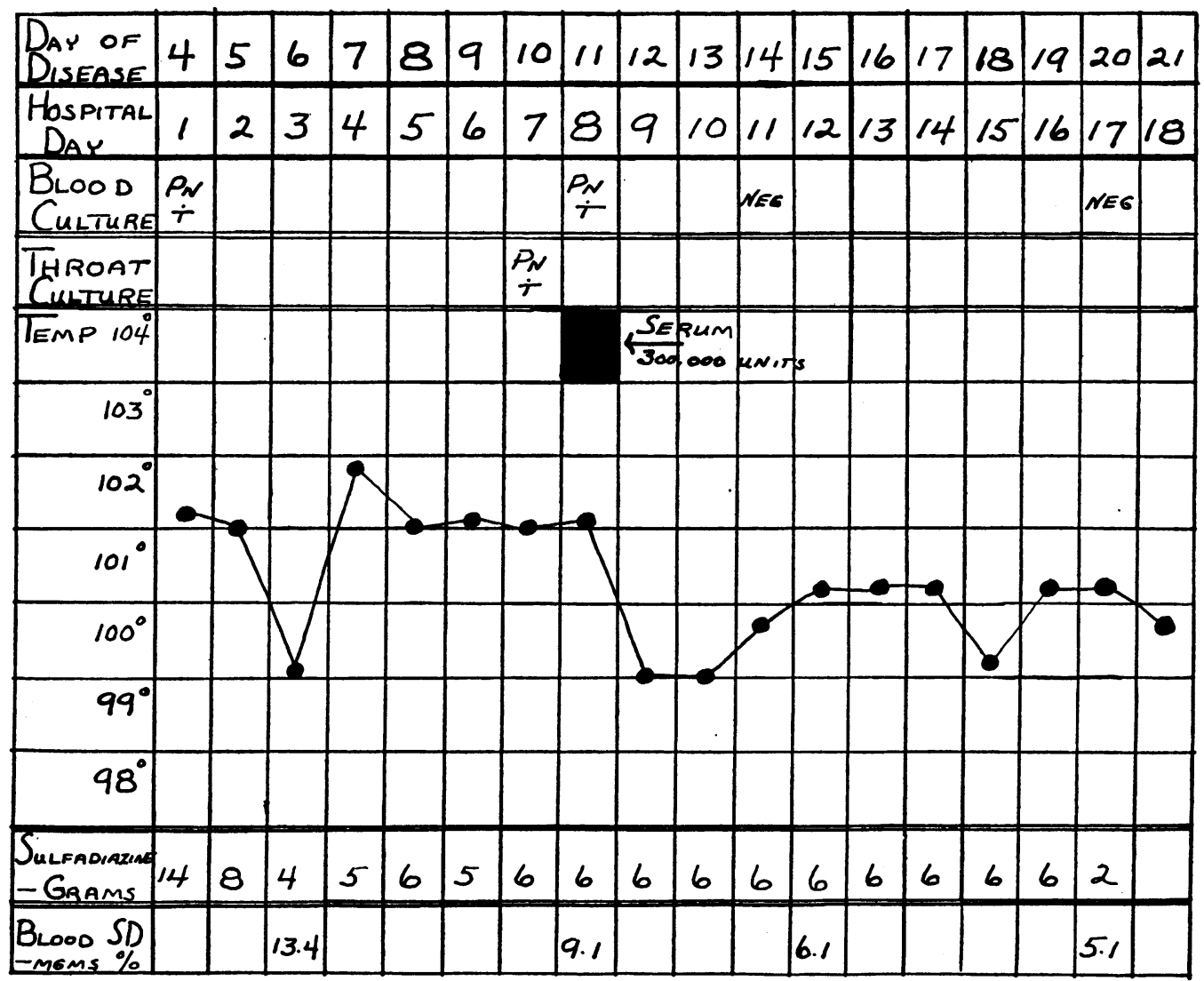

Fig. 1. Patient M. R.; Type I Pneumococcus Pneumonia

years. He was admitted the day after onset of pneumonia which began with chill and sharp pain in left chest.

On admission, there were signs of early pneumonia in the left upper lobe. The leukocyte count was 9,000. Pneumococcus Type VIII was present in sputum and also in the first blood culture. The Wassermann reaction was positive.

Chemotherapy was begun on admission with sulfathiazole, but later changed to sulfadiazine. There was no improvement in the first three days and, as indicated in Figure 2, the temperature increased on the fourth hospital day. Daily blood cultures were positive for the first five days. Signs of a small pleural effusion were present on the fifth day. Five to $10 \mathrm{cc}$. of thin cloudy fluid were obtained by thoracentesis, a culture of which yielded pneumococcus Type VIII. The sulfonamide level in the pleural fluid was $4.3 \mathrm{mgm}$. per cent. This strain was used in laboratory studies, the results of which are presented in Table I and discussed later.

Antipneumococcus rabbit serum, administered on the fifth and sixth hospital days, brought about marked clinical improvement. Subsequent blood cultures were sterile. The small encysted empyema persisted. Numerous subsequent attempts were made to obtain fluid but in only one instance, on the eighteenth day, were 2 to $3 \mathrm{cc}$. of a bloody exudate obtained. Pneumococcus Type VIII was present in the specimen. The area subsequently resolved and the patient was discharged from the hospital on the sixtieth day.

As noted in Figure 2, pneumococci and levels of sulfonamide of from 5.8 to $7.6 \mathrm{mgm}$. per cent were present concurrently in the blood stream. Although the organisms of the blood cultures were not tested, the first culture of the pleural fluid yielded pneumococcus Type VIII, which, when used for infection in mice, proved refractory to treatment with sulfadiazine. The course in this case, on the basis of a persistent bacteremia as demonstrated by daily blood cultures, suggests, perhaps more definitely than the first case, the probability that the infecting strain was drug-fast from the beginning of the illness.

\section{DISCUSSION}

A review of the literature indicates that up to the present time the incidence of cases of pneumonia caused by drug-fast strains is a small fraction of the total. Ross (4) reported a strain from a fatal case of meningitis which, by cultural tests, was susceptible to sulfonamide bacteriostasis early 
in the disease but a second culture obtained at autopsy was drug-resistant. Hamburger and associates (7) described a strain of pneumococcus from a case of bacterial endocarditis which, following prolonged chemotherapy, acquired drugresistant characteristics, as demonstrated in vitro. Other observers, in studying strains derived from cases of pneumonia, have noted variations in the capacity of the organism to multiply in culture media containing stated quantities of sulfonamide drugs. In early cases of uncomplicated pneumonia, Lowell, Strauss, and Finland (6) did not encounter resistant strains among those isolated before treatment was begun. In three instances, they observed strains that were relatively resistant after a few days of chemotherapy. In some patients who failed to respond to drug treatment, however, no change in the susceptibility of the strains, which might account for the unsatisfactory results, was noted. Cotler, Kirchner, and Romano (8) cultivated specimens of material from cases of pneumonia on blood agar containing varying amounts of sulfapyridine. They cited five cases in which the lack of therapeutic effect of the drug was particularly striking. In three of the instances, the strains were drug-resistant in that colonies developed on blood agar containing sulfapyridine. By testing pneumonic sputum injected into treated mice, Moore, Thomas, and Hoyt (9) found one strain of pneumococcus, out of thirty-three derived from different patients with pneumonia, to be sulfonamide resistant.

In a recent report, Tillett (10) noted that during a two-year period of observation on chemotherapy in pneumonia, pneumococcus bacteremia was found to persist for as long as seven days only in cases complicated by endocarditis. The two cases of the present report are obvious exceptions to the earlier experience.

A noteworthy feature of the clinical course of the two patients described in the present report was the rapid and satisfactory response to serum

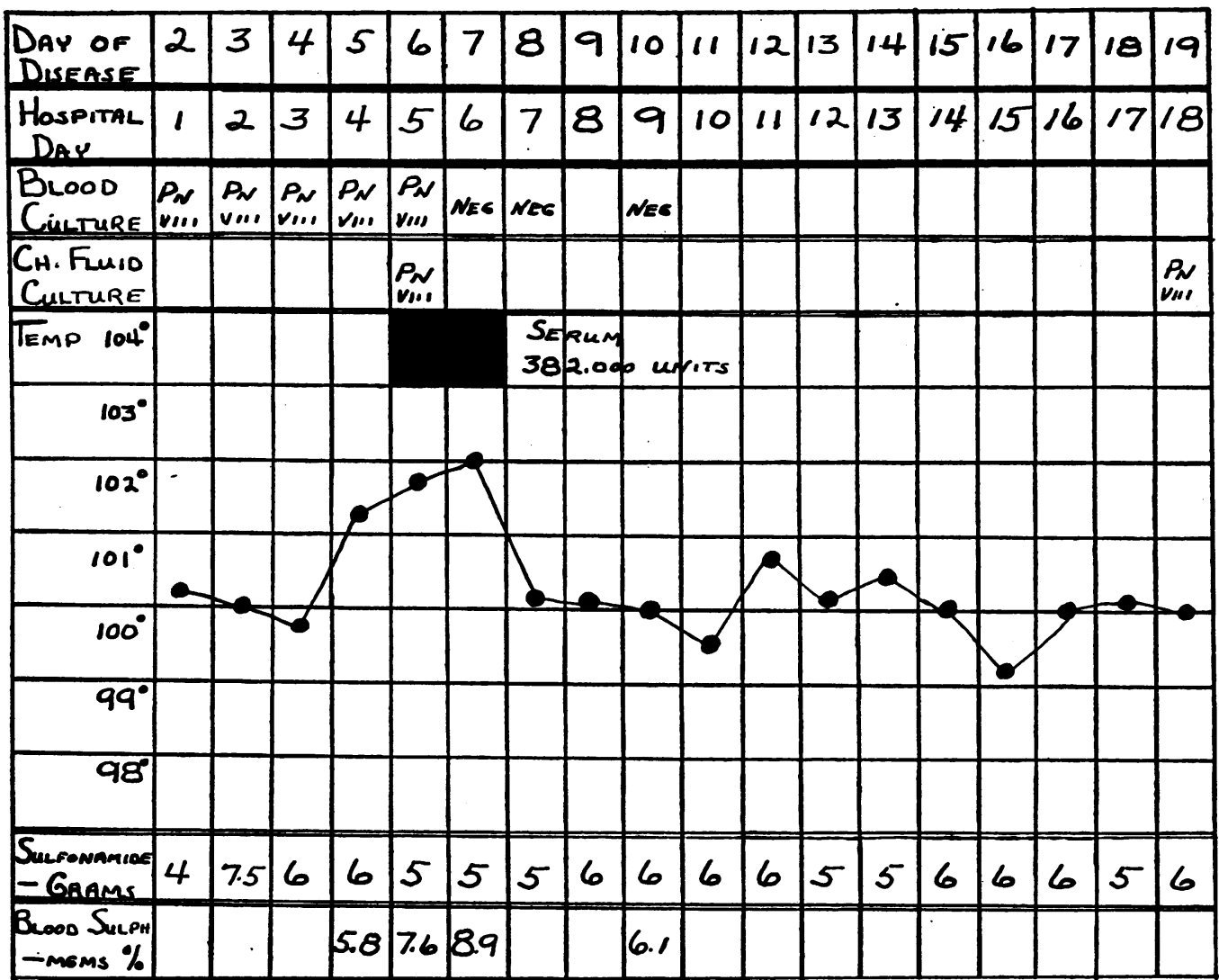

Fig. 2. Patient W. L.; Type Vili Pneumococcus Pneumonia 
therapy. MacLeod and Daddi (2) found infections in mice, produced by the resistant strain of pneumococcus Type I which they employed, to be just as amenable to cure with antipneumococcus serum as were infections with susceptible strains of Type I. Lowell, Strauss, and Finland (6) observed rapid improvement in two patients who were treated with serum following a relapse of pneumonia which developed during sulfapyridine therapy. The strains from their two cases were found by cultural methods to be drug-resistant.

Experimental studies with patients' strains of pneumococci Types $I$ and VIII in relation to therapeutic use of sulfadiazine, penicillin, and tyrothricin

The sources of four strains of pneumococci used in the tests were as follows: Type I resistant strain came from a throat culture taken on patient M. $R$. on the seventh hospital day. Type VIII resistant strain came from the pleural fluid of patient W. L. obtained on the fifth hospital day. Type I and Type VIII susceptible strains were stock laboratory cultures.

Infections in mice were produced with each of the four strains by intraperitoneal injection of graded amounts of the respective cultures.

The preparation of the material and the methods of treatment with sulfadiazine, penicillin, and tyrothricin were as follows:

Sulfadiazine. The drug in powder form was suspended in gum tragacanth. Treatment was given per os by means of a small silver catheter used as a stomach tube. A dose of $20 \mathrm{mgm}$. per treatment was most regularly employed, twice on the first day and once daily thereafter for three to four days. The amount of drug for a single dose was contained in $0.5 \mathrm{cc}$. of the mixture of sulfadiazine and tragacanth. The infecting dose of culture was injected five to ten minutes after the first oral administration.

Penicillin. The powdered material was received in sealed ampoules. ${ }^{1}$ Each ampoule contained 5,000 so-called Florey units (11). The contents of a single ampoule were dissolved in 10 cc. of distilled water which yielded a clear yellowish solution containing 500 units per cc. The data presented in Table I consist of the combined results which were obtained when either $0.5 \mathrm{cc}$.

\footnotetext{
1 Penicillin was obtained from E. R. Squibb and Son.
}

of the original solution ( 250 units) or $0.5 \mathrm{cc}$. of a 1-10 dilution (25 units) were employed. For the data given in Table $I$, mice received penicillin three times daily, by the intraperitoneal route, for four days. The first injection was given ten to fifteen minutes after the infection.

Tyrothricin. The material was made available by Dr. Colin MacLeod who obtained it from Merck \& Company. The term tyrothricin was applied by Dubos and Hotchkiss (12) to material which contains both gramicidin and tyrocidin. Although more toxic than gramicidin, the curative action of tyrothricin for experimental pneumococcal infections has been established (12).

The powder was dissolved in absolute alcohol, in sufficient quantity to make a 4 per cent solution. Additional dilutions were made in distilled $\mathrm{H}_{2} \mathrm{O}$ so that $1 \mathrm{cc}$. contained either $0.04 \mathrm{mgm}$. or $0.08 \mathrm{mgm}$. Each mouse received, as the total treatment, one single dose of $0.5 \mathrm{cc}$. $(0.02 \mathrm{mgm}$. or $0.04 \mathrm{mgm}$.) intraperitoneally, within a few minutes after the infection.

The combined results of different experiments concerning the curative action of the three reagents, sulfadiazine, penicillin, and tyrothricin, for the four strains of pneumococci are contained in Table I.

From Table I, it may be noted that no therapeutic effect was obtained with sulfadiazine against the two patients' strains, even when the amount of infecting inoculum was as small as $10^{-6}$ dilution of culture. Against the two stock strains, however, effective cure was uniformly obtained against $10^{-2} \mathrm{cc}$. of culture.

The negative therapeutic results with the resistant strains were obtained in the first tests performed within a few days after their isolation and also in similar tests made three months later. The persistence of the drug-fast qualities by resistant strains, noted in the cutures used in the present experiments, has also been reported by other investigators (2).

In contrast to the selective results obtained by treatment with sulfadiazine, when penicillin was employed the curative action was equally great against all four strains. The data in Table I demonstrate that the mice uniformly survived, whether they received maximum doses $\left(10^{-2} \mathrm{cc}\right)$ of sulfonamide-resistant strains or comparable amounts of susceptible strains. 
TABLE I

Therapeutic action of sulfadiazine, penicillin, and tyrothrycin in mice infected with patients' strains and stock strains of pneumococci Types I and VIII

\begin{tabular}{|c|c|c|c|c|c|c|c|c|c|c|}
\hline \multicolumn{2}{|c|}{ Cultures } & \multicolumn{3}{|c|}{ Sulfadiazine } & \multicolumn{3}{|c|}{ Penicillin } & \multicolumn{3}{|c|}{ Tyrothrycin } \\
\hline Strain & $\begin{array}{c}\text { Amount of } \\
\text { inoculum }\end{array}$ & $\underset{\text { mice }}{\text { Number }}$ & $\begin{array}{l}\text { Number } \\
\text { survivals }\end{array}$ & $\begin{array}{l}\text { Per cent } \\
\text { survivals }\end{array}$ & $\begin{array}{c}\text { Number } \\
\text { mice }\end{array}$ & $\begin{array}{l}\text { Number } \\
\text { survivals }\end{array}$ & $\begin{array}{l}\text { Per cent } \\
\text { survivals }\end{array}$ & $\underset{\text { mice }}{\text { Number }}$ & $\begin{array}{l}\text { Number } \\
\text { survivals }\end{array}$ & $\begin{array}{l}\text { Per cent } \\
\text { survivals }\end{array}$ \\
\hline $\begin{array}{l}\text { Type I } \\
\text { M. R. } \\
\text { (patient) }\end{array}$ & $\begin{array}{l}10^{-2} \\
10^{-8} \\
10^{-4} \\
10^{-8} \\
10^{-6}\end{array}$ & $\begin{array}{l}4 \\
6 \\
3 \\
6 \\
8\end{array}$ & $\begin{array}{l}0 \\
0 \\
0 \\
0 \\
0\end{array}$ & $\begin{array}{l}0 \\
0 \\
0 \\
0 \\
0\end{array}$ & $\begin{array}{l}6 \\
8\end{array}$ & $\begin{array}{l}6 \\
8\end{array}$ & $\begin{array}{l}100 \\
100\end{array}$ & $\begin{array}{l}8 \\
8\end{array}$ & $\begin{array}{l}6 \\
7\end{array}$ & $\begin{array}{l}75 \\
87\end{array}$ \\
\hline $\begin{array}{l}\text { Type I } \\
\text { (Stock) }\end{array}$ & $\begin{array}{l}10^{-2} \\
10^{-3} \\
10^{-4} \\
10^{-8} \\
10^{-}\end{array}$ & $\begin{array}{l}6 \\
5 \\
3 \\
3 \\
3\end{array}$ & $\begin{array}{l}6 \\
5 \\
3 \\
3 \\
3\end{array}$ & $\begin{array}{l}100 \\
100 \\
100 \\
100 \\
100\end{array}$ & $\begin{array}{l}5 \\
6\end{array}$ & $\begin{array}{l}5 \\
6\end{array}$ & $\begin{array}{l}100 \\
100\end{array}$ & $\begin{array}{l}8 \\
8\end{array}$ & $\begin{array}{l}7 \\
8\end{array}$ & $\begin{array}{r}87 \\
100\end{array}$ \\
\hline $\begin{array}{c}\text { Type VIII } \\
\text { W. L. } \\
\text { (patient) }\end{array}$ & $\begin{array}{l}10^{-2} \\
10^{-8} \\
10^{-4} \\
10^{-4} \\
10^{-6}\end{array}$ & $\begin{array}{r}4 \\
10 \\
4 \\
6 \\
8\end{array}$ & $\begin{array}{l}0 \\
0 \\
0 \\
0 \\
0\end{array}$ & $\begin{array}{l}0 \\
0 \\
0 \\
0 \\
0\end{array}$ & $\begin{array}{r}6 \\
10\end{array}$ & $\begin{array}{r}6 \\
10\end{array}$ & $\begin{array}{l}100 \\
100\end{array}$ & $\begin{array}{l}8 \\
8\end{array}$ & $\begin{array}{l}7 \\
8\end{array}$ & $\begin{array}{r}87 \\
100\end{array}$ \\
\hline $\begin{array}{c}\text { Type VIII } \\
\text { (Stock) }\end{array}$ & $\begin{array}{l}10^{-2} \\
10^{-2} \\
10^{-4} \\
10^{-6} \\
10^{-6}\end{array}$ & $\begin{array}{r}5 \\
10 \\
5 \\
5 \\
5\end{array}$ & $\begin{array}{r}5 \\
10 \\
5 \\
5 \\
5\end{array}$ & $\begin{array}{l}100 \\
100 \\
100 \\
100 \\
100\end{array}$ & $\begin{array}{l}5 \\
5\end{array}$ & $\begin{array}{l}5 \\
5\end{array}$ & $\begin{array}{l}100 \\
100\end{array}$ & $\begin{array}{l}8 \\
8\end{array}$ & $\begin{array}{l}2 \\
6\end{array}$ & $\begin{array}{l}25 \\
75\end{array}$ \\
\hline
\end{tabular}

In control mice, used in each separate experiment, an inoculum of $10^{-6}$ of culture of each strain proved uniformly fatal.

Fleming (13) who first described the action of penicillin, found that the material inhibited the growth of gram positive cocci. Subsequently Chain, et al. (11), Florey, et al. (14), and Hobby, Meyer, and Chaffee (15) have demonstrated in vivo activity against pneumococci. Powell and Jamieson (16) have found penicillin to be effective against sulfonamide-fast strains of pneumococci. McKee and Rake (17), in a brief report, state that mice infected with sulfonamideresistant strains of pneumococci have been protected with penicillin. Florey and Jennings (18) remarked upon the fact that sulfonamide-resistant strains of streptococci were sensitive to penicillin.

When tyrothricin in single doses per mouse of $0.02 \mathrm{mgm}$. or $0.04 \mathrm{mgm}$. was used for treatment, the extent of protection afforded the mice was found in different experiments to be variable. In comparing the results (Table I) obtained with each of the four strains, it may be noted, however, that there was no evidence of special refractoriness exhibited by the mice infected with the sulfonamide-resistant strains. On the contrary, among the infections caused by the four strains, tyrothricin was found to be least effective against one of the stock strains (Type VIII) which is sulfonamide susceptible. Consequently, the findings have failed to indicate any relationship between sulfonamide resistance and factors which influence the effect of tyrothricin on pneumococci.

\section{Tests for the production of sulfonamide inhibiting substances by strains of pneumococci}

Repeated studies have demonstrated that the resistance of bacteria to the action of the sulfonamides is not infrequently associated with the production of inhibiting substances by the refractory strains. MacLeod (19) reported results obtained with a strain of pneumococcus which was made sulfonamide-fast in vitro. The strain was found to produce significant amounts of inhibitor. The same author has also referred to other resistant strains of pneumococci which, however, did not produce demonstrable amounts of anti-sulfonamide substances (20).

Both the resistant and susceptible strains used in the present study have been tested for the capacity to produce inhibitor. As a positive control of the technique employed, the resistant Type I strain of MacLeod was also used in comparative tests. 
The tests were carried out according to the procedure reported by MacLeod (19), using a strain of $\mathrm{B}$. coli cultivated in the special media described by Sahyun, Beard, Schultz, Snow, and Cross (21). Into the tubes containing $5.0 \mathrm{cc}$. of basic media, serial dilutions of sulfadiazine were added. The strain of $\mathrm{B}$. coli grew in the presence of 1 part in 2,000,000 (equivalent to $0.0025 \mathrm{mgm}$.) of sulfadiazine but was inhibited by 1 part in 1,000 ,000 ( $0.005 \mathrm{mgm}$.) of the drug.

The five strains of pneumococci used in the tests were first cultivated in the synthetic media described by Bernheimer, Pappenheimer and associates (22). In preliminary trials, sterile uninoculated preparations of the media were found to be devoid of inhibitor commonly encountered in broth. Five tenths cc. of the supernatant fluid of cultures of pneumococci was added to the basic materials, and the tubes were inoculated with $10^{-4}$ dilution of B. coli. Since the pneumococci were unable to grow in the media of Sahyun, Beard, et al., either with or without B. coli, it was unnecessary to heat the cultures of pneumococci before adding the supernatant fluid to the other elements of the test. The results are given in Table II.
From the data of Table II, it may be seen that a moderate but equal amount of inhibiting substance was developed by both the sulfonamide-fast patient's strain of Type I and the sulfonamidesusceptible stock Type I. Consequently, on the basis of the test, the two strains could not be differentiated. However, with the drug-fast Type I strain of MacLeod, the production of inhibitor was greatly increased over that of the other strains.

With the Type VIII cultures, the yield of inhibitor by the sulfonamide-susceptible stock strain was comparable to that of the Type I stock strain. Cultures of the sulfonamide-resistant strain from patient W. L. were the weakest of any of the strains in the production of inhibiting substances.

On the basis, therefore, of the findings summarized in Table II, it has not been possible to ascribe the resistance of the patients' strains to the production of sulfonamide inhibiting substances. Furthermore, the results obtained with patient's Type I strain and with MacLeod's Type I strain appear significant in indicating that among strains of pneumococci, even of the same type, different mechanisms may exist for nullifying the action of the sulfonamide drugs.

TABLE II

Tests for production of inhibitor by five strains of pneumococci

\begin{tabular}{|c|c|c|c|c|c|c|}
\hline \multirow{2}{*}{$\begin{array}{c}\text { Supernatant fluid } \\
\text { Strain }\end{array}$} & \multicolumn{6}{|c|}{ Dilutions of sulfadiazine in synthetic media* } \\
\hline & $\begin{array}{c}1 \\
\text { to } \\
20,000\end{array}$ & $\begin{array}{c}1 \\
\text { to } \\
50,000\end{array}$ & $\begin{array}{c}1 \\
\text { to } \\
100,000\end{array}$ & $\begin{array}{c}1 \\
\text { to } \\
500,000\end{array}$ & $\begin{array}{c}1 \\
\text { to } \\
1,000,000\end{array}$ & $\begin{array}{c}1 \\
\text { to } \\
2,000,000\end{array}$ \\
\hline $\begin{array}{c}\text { Type I } \\
\text { M. R. (patient) }\end{array}$ & 一 & - & 一 & +++ & ++++ & $+++t$ \\
\hline $\begin{array}{l}\text { Type I } \\
\text { (Stock) }\end{array}$ & 一 & - & 一 & +++ & +++ & ++++ \\
\hline $\begin{array}{c}\text { Type I } \\
\text { (MacLeod) }\end{array}$ & +++ & +++ & +++ & +++ & +++ & $+t+t$ \\
\hline $\begin{array}{c}\text { Type VIII } \\
\text { W. L. (patient) }\end{array}$ & - & - & 一 & 一 & - & ++++ \\
\hline $\begin{array}{c}\text { Type VIII } \\
\text { (Stock) }\end{array}$ & 一 & 一 & 一 & +++ & ++++ & ++++ \\
\hline $\begin{array}{c}\text { Sterile } \\
\text { Pneumococcus } \\
\text { Media }\end{array}$ & 一 & 一 & - & - & 一 & $+++t$ \\
\hline Control & 一 & 一 & 一 & - & - & $+t+t$ \\
\hline
\end{tabular}

,+++++++ indicate visible density of growth of B. coli, - indicates no visible growth. Final readings of growth were made after $\mathbf{4 8}$ hours incubation.

* Sahyun, Beard, et al. (21)

$\dagger$ Bernheimer, Gillman, et al. (22). 


\section{SUMMARY}

1. From two patients having pneumonia and bacteremia, strains of pneumococci (Types I and VIII) were isolated which caused infections in mice, that were totally refractory to treatment with sulfadiazine.

The clinical course of the patients and the clinical laboratory data (blood cultures and levels of sulfonamides in blood) also indicated the drugresistant characteristics of the infection.

Both patients responded rapidly and successfully to specific serum therapy.

2. In experimental observations, penicillin was found to be highly effective against infections in mice caused by either sulfonamide-resistant or susceptible strains.

When tyrothricin in single doses was used for treatment of mice, the protection was not uniformly complete against any one of the strains. However, no evidence was obtained to indicate that sulfonamide resistance influenced the effect of tyrothricin.

3. It was not possible to demonstrate that the drug-resistance of the patients' strains was due to the production of inhibiting substances. By contrast, cultures of an additional strain of Type I pneumococcus (MacLeod) were found to yield considerable amounts of inhibitor.

\section{BIBLIOGRAPHY}

1. MacLean, I. H., Rogers, K. B., and Fleming, A., M. and B. 693 and pneumococci. Lancet, 1939, 1, 562.

2. MacLeod, C. M., and Daddi, G., A sulfapyridine-fast strain of pneumococcus Type I. Proc. Soc. Exper. Biol. and Med., 1939, 41, 69.

3. Schmidt, L. H., Sesler, C. L., and Dettwiler, H. A., Studies on sulfonamide-resistant organisms. 1. Development of sulfapyridine resistance by pneumococci. J. Pharmacol. and Exper. Therap., 1942, 74, 175.

4. Ross, R. W., Acquired tolerance of pneumococcus to M. \& B. 693. Lancet, 1939, 1, 1207.

5. Long, P. H., and Bliss, E. A., Observations upon the experimental use of sulfapyridine. I. The relation of strain resistance to the chemotherapeutic effects of sulfapyridine in experimental pneumococcal infections in mice. Ann. Int. Med., 1939, 13, 232.

6. Lowell, F. C., Strauss, E., and Finland, M., Observations on the susceptibility of pneumococci to sulfapyridine, sulfathiazole, and sulfamethylthiazole. Ann. Int. Med., 1940, 14, 1001.

7. Hamburger, M., Jr., Schmidt, L. H., Rueglegger, J. M., Sesler, C. L., and Gruper, E. S., Sulfonamide resistance developing during treatment of pneumococcic endocarditis. J. A. M. A., 1942, 119, 409.

8. Cotler, H. Y., Kirchner, M. T., and Romano, M., Recognition of sulfapyridine-fast pneumococci. Proc. Soc. Exper. Biol. and Med., 1941, 46, 241.

9. Moore, F. J., Thomas, R. E., and Hoyt, A., Sensitivity of pneumococci to sulfapyridine. J. A. M. A., 1941, 117, 437.

10. Tillett, W. S., Specific antipneumococcal immunity in relation to the chemotherapy of pneumonia. J. Clin. Invest., 1942, 21, 511.

11. Chain, E., Florey, H. W., Gardner, A. D., Heatley, N. G., Jennings, M. A., Orr-Ewing, J., and Sanders, A. G., Panicillin as a chemotherapeutic agent. Lancet, 1940, 2, 226.

12. Dubos, R. J., and Hotchkiss, R. D., Origin, nature and properties of gramicidin and tyrocidine. $\mathrm{Tr}$. and Stud., Coll. of Physicians, Philadelphia, 1942, $10,11$.

13. Fleming, A., On antibacterial action of cultures of penicillium with special reference to their use in isolation of B. influenzae. Brit. J. Exper. Path., 1929, 10, 226.

14. Abraham, E. P., Chain, E., Fletcher, C. M., Gardner, A. D., Heatley, N. G., Jennings, M. A., and Florey, H. W., Further observations on penicillin. Lancet, 1941, 2, 177.

15. Hobby, G. L., Meyer, K., and Chaffee, E., (a) Activity of penicillin in vitro. (b) Observations on the mechanism of action of penicillin. (c) Chemotherapeutic activity of penicillin. Proc. Soc. Exper. Biol. and Med., 1942, 50, pp. 277 (a), 281 (b); 285 (c).

16. Powell, H. M., and Jamieson, W. A., Response of sulfonamide-fast pneumococci to penicillin. Proc. Soc. Exper. Biol. and Med., 1942, 49, 387.

17. McKee, C. M., and Rake, G., Biological experiments with penicillin. J. Bact., 1942, 43, 645.

18. Florey, H. W., and Jennings, M. A., Some biological properties of highly purified penicillin. Brit. J. Exper. Path., 1942, 23, 120.

19. MacLeod, C. M., The inhibition of bacteriostatic action of sulfonamide drugs by substances of animal and bacterial origin. J. Exper. Med., 1940, 72, 217.

20. MacLeod, C. M., The antibacterial action of the sulfonamide drugs. (In press.)

21. Sahyun, M., Beard, P., Schultz, E. W., Snow, J., and Cross, E., Growth stimulating factors for microörganisms. J. Infect. Dis., 1936, 58, 28.

22. Bernheimer, A. W., Gillman, W., Hottle, G. A., and Pappenheimer, A. M., Jr., An improved medium for the cultivation of hemolytic streptococcus. J. Bact., 1942, 43, 495. 